\title{
INTELECTUAIS PÚBLICOS BRASILEIROS E A PANDEMIA GLOBAL DE COVID-19: PERSPECTIVAS
}

\section{REVISÃO INTEGRATIVA}

TEIXEIRA, Adriana ${ }^{1}$

BERNARDO, Kaluan ${ }^{2}$

ARRUDA, Renê Eduardo ${ }^{3}$

TEIXEIRA, Adriana. BERNARDO, Kaluan. ARRUDA, Renê Eduardo. Intelectuais públicos brasileiros e a pandemia global de covid-19: Perspectivas. Revista Científica Multidisciplinar Núcleo do Conhecimento. Ano 05, Ed. 11, Vol. 13, pp. 0525. Novembro de 2020. ISSN: 2448-0959, Link de acesso: https://www.nucleodoconhecimento.com.br/comunicacao/intelectuais-

publicos

\section{RESUMO}

Intelectuais públicos são frequentemente convidados por meios de comunicação para proporem conceitos, percepções e reflexões acerca de debates, discursos e fenômenos contemporâneos. No contexto da pandemia global de covid-19, dezenas de textos de autoria de intelectuais foram difundidos, cada um deles propondo uma via de análise distinta sobre diversos aspectos do cenário contemporâneo, dentre elas a quarentena, política, sistema econômico, poder, sociedade e vigilância. Como

\footnotetext{
${ }^{1}$ Mestre em Comunicação e Semiótica pela PUC-SP e Doutoranda em Comunicação e Semiótica pela PUC-SP.

2 Mestre em Comunicação e Semiótica pela Cásper Líbero e Doutorando em Comunicação e Semiótica pela PUC-SP.

${ }^{3}$ Mestre em Comunicação e Semiótica pela PUC-SP e Doutorando em Comunicação e Semiótica pela PUC-SP.
} 
qualquer fenômeno global, a pandemia tem especificidades decorrentes do contexto social e político local. Intelectuais públicos brasileiros têm considerado estas especificidades do contexto nacional em suas análises. Este artigo tem por objetivo apresentar um panorama das análises de intelectuais públicos brasileiros sobre o fenômeno da pandemia de covid-19 no Brasil, mapeando conceitos, percepções e perspectivas de seus textos publicados em meios de comunicação.

Palavras-chave: quarentena, intelectuais públicos, pandemia, covid-19.

\section{INTRODUÇÃO}

Intelectuais públicos são frequentemente contatados por meios de comunicação para divulgarem suas análises sobre fenômenos contemporâneos, posicionando-se em meio a debates, propondo conceitos e traçando perspectivas. Meios de comunicação confiam a estes profissionais, pesquisadores e estudiosos um espaço privilegiado de fala na esperança de que, detentores de conhecimento específico, possam vir a esclarecer anseios do público, aprofundar e ampliar debates, desmistificar discursos e propor novos horizontes de ação.

O intelectual público, ao menos enquanto conceito, é uma invenção francesa (DOMINGUES, 2011), cuja origem estaria nos hommes de lettres citados por Alexis de Tocqueville em "O Antigo Regime e a Revolução". Para o autor francês, são intelectuais públicos os filósofos, escritores e "livres pensadores" que, munidos de ideias, aptos à participação política e capazes de persuadir o público, ocuparam a arena política antes e durante o período histórico da Revolução Francesa. Portanto, nesta concepção, o intelectual público não é apenas detentor ou produtos de conhecimento, mas agente político, definido por sua capacidade de persuasão e de ação reformadora da sociedade.

O Prof. Dr. Ivan Domingues, professor titular de Filosofia e coordenador do Núcleo de Estudos do Pensamento Contemporâneo da Faculdade de Filosofia, Letras e Ciências Humanas da UFMG (Universidade Federal de Minas Gerais), disserta em seu artigo "O intelectual público, a ética republicana e a fratura do éthos da ciência" (2011) que 
o intelectual público francês encontra equivalentes em outros países e ocupa a cena política ao longo do século XX até suas últimas décadas.

Para Domingues, o intelectual público é caracterizado por seu engajamento a causas políticas e por uma ética republicana, uma "virtude cívica ou a fusão da virtude moral e da virtude política" (2011, p. 470), uma combinação que resultaria na renúncia de interesses particulares em favor do interesse geral, respeito ao outro e solidariedade, e cujo horizonte é a humanidade em vez de um grupo específico.

Ao fim do século XX, o intelectual público de Tocqueville entra em crise, segundo Domingues, pelo "eclipse quase total da política" (p. 469) devido à indiferença dos povos nacionais ao respeito à moral pública, e em especial à relação entre moral e política.

E foi então que o intelectual total, engajado, cidadão do mundo e falando em nome da humanidade, a exemplo de Diderot, Zola e Sartre, chegou ao fim e, em seu lugar, ficou o intelectual específico (Foucault), o expert (como se via Lévi-Strauss) e o acadêmico (uma legião). Também eles poderão ocupar a cena pública, mas sem engajamento político ou partidário, emitindo opiniões técnicas quando solicitados, nada mais. (2011, p. 469)

Ainda que o intelectual total tenha entrado em crise, e que o intelectual específico, o expert e o acadêmico tenham, por definição, menor capacidade de ação política reformadora da sociedade, não significa que suas posições, arguições e perspectivas são inócuas na arena política, na cultura e na sociedade. O espaço de fala conferido por meios de comunicação a estas categorias de intelectuais públicos deriva de sua potencial capacidade de ampliar e aprofundar os debates acerca de assuntos de interesse geral, efetivamente abrindo novas vias de compreensão, validando ou degradando discursos específicos e proporcionando perspectivas e horizontes de análise e previsão, especialmente em cenários de grande incerteza social e econômica. 


\subsection{PANDEMIA DE COVID-19 NO BRASIL}

Em 11 de março de 2020, a Organização Mundial da Saúde (OMS) declarou o surto de covid-19 uma pandemia global, apontando para os mais de 118 mil casos registrados em mais de 110 países e territórios ao redor do mundo à época (OMS, 2020). A entidade internacional recomendou que todos os países com casos registrados da doença deveriam ativar e ampliar seus mecanismos de resposta a emergências, comunicar riscos e formas de proteção à população geral e trabalhadores da área da saúde, e reduzir a transmissão por meio de isolamento social. Em 25 de maio do mesmo ano, a doença teria 5,4 milhões de casos registrados ao redor do mundo, sendo responsável direta ou indiretamente por ao menos $350 \mathrm{mil}$ mortes (BBC, 2020).

Em 25 de maio de 2020, as secretarias estaduais de Saúde brasileiras confirmam mais de 370 mil casos de covid-19, resultando em ao menos 23 mil mortes. Naquela data, o Brasil já era o segundo país do mundo em quantidade de casos confirmados da doença, atrás somente dos Estados Unidos da América.

Desde março, autoridades municipais e estaduais do Brasil têm recomendado isolamento social para redução da taxa de contágio da covid-19, impondo diversas medidas locais com vistas à prevenção da doença e tratamento dos infectados, como fechamento do comércio não-essencial, uso de máscaras, distanciamento social obrigatório, lockdown (bloqueio completo de uma região) etc. Estas medidas levaram a um conflito político (e também, muitas vezes, jurídico) entre governos municipais e estaduais com governo federal - que, em diversas oportunidades, priorizou a continuidade das atividades econômicas e posicionou-se contra as recomendações da OMS.

A pandemia no Brasil traz à tona outras complexidades: as condições de moradia das populações de baixa renda, com infraestrutura mínima ou inexistente, e a proximidade entre unidades residenciais e quantidade de moradores por residência intensificam as possibilidades de transmissão da doença. A desigualdade de renda por vezes se traduz em desigualdade de acesso à saúde e de condições para respeitar o 
isolamento social e a quarentena determinada por governadores e prefeitos. Estas e muitas outras características e condições do Brasil fazem com que a pandemia tenha, em território nacional, contornos muitos diferentes daqueles em outros países.

A pandemia e suas consequências no Brasil para a saúde pública, estabilidade política nacional, economia, relações interpessoais e de trabalho, cultura, dentre outros aspectos da vida em sociedade, compõem um cenário de grande incerteza e instabilidade, em todos os níveis e para todos os cidadãos brasileiros. Este artigo tem como objetivo apresentar um panorama das análises de intelectuais públicos brasileiros acerca do fenômeno pandemia de covid-19 no Brasil, integrando conceitos, percepções e perspectiva de seus textos publicados em meios de comunicação.

\section{METODOLOGIA}

O presente artigo foi elaborado a partir de uma metodologia de quatro fases, sendo elas: (1) definição da amostra de intelectuais públicos a ser considerada no artigo; (2) definição da amostra de textos de cada autor; (3) síntese dos textos selecionados, mapeando os conceitos e relações estabelecidas por cada autor e (4) diálogo entre perspectivas de cada autor.

\subsection{SELEÇÃO DE INTELECTUAIS PÚBLICOS}

Dada a crise do intelectual público total e a relativa escassez de critérios objetivos para a distinção entre intelectual público, intelectual em sentido amplo, celebridade, expert e acadêmico, optamos, por razões metodológicas, por definir intelectual público a partir de dois critérios: visibilidade midiática e respeitabilidade.

Visibilidade midiática é a presença em mídias de amplo acesso, seja em canais de televisão e rádio, ou mídias sociais como YouTube, revistas, jornais e websites noticiosos. Respeitabilidade é a qualidade do intelectual que possui reconhecimento de seus pares como alguém que domina determinado campo do conhecimento.

Considerando que a pandemia no Brasil tem especificidades importantes, optamos por realizar também um recorte geográfico dos autores cujos textos foram analisados 
neste artigo. Foram selecionados autores que atendem aos critérios de visibilidade midiática e respeitabilidade, e que são brasileiros - têm residência no país, nele produzem e convivem.

Por fim, há um terceiro recorte de autores. Considerando que há múltiplos autores de diversas áreas do conhecimento, optamos por selecionar para análise apenas um autor de cada área de conhecimento que tem diálogo com o campo da Comunicação.

Assim, os textos analisados neste artigo são dos seguintes autores: Aílton Alves Lacerda Krenak (ambientalista e líder indígena); Fernando Reinach (biólogo e professor titular da Universidade de São Paulo), Lilia Schwarcz (historiadora e professora titular da Faculdade de Filosofia, Letras e Ciências Humanas da Universidade de São Paulo); Ricardo Abramovay (economista e professor sênior do Instituto de Energia da Universidade de São Paulo); Sidarta Ribeiro (neurocientista e fundador do Instituto do Cérebro); Angela Alonso (socióloga e professora do Departamento de Sociologia da Universidade de São Paulo) e Tales Ab'Saber (psicanalista e professor do curso de Filosofia da Universidade Federal de São Paulo).

\subsection{SELEÇÃO DE TEXTOS DE CADA AUTOR}

Os textos selecionados para síntese e posterior diálogo foram eleitos a partir de dois critérios: temático e temporal. Cada texto deveria ter, como principal assunto, a pandemia de covid-19 no Brasil; e ter sido publicado entre o início de março e o fim do mês de junho de 2020. O recorte temporal selecionado destaca-se por tratar-se dos primeiros meses do que viria a ser uma longa pandemia, marcado por incertezas e por medidas urgentes que solaparam o estado de normalidade para outro patamar.

\subsection{SÍNTESE}

Os textos selecionados de cada autor foram sintetizados seguindo uma estratégia de identificação dos temas e resumo de argumentos. A identificação dos temas se refere à criação de uma lista resumindo as relações que cada autor estabelece a partir do fenômeno (pandemia de covid-19) - ou seja, quais outros fenômenos cada autor 
argumenta que estão relacionados com a pandemia. O resumo de argumentos, por outro lado, busca sintetizar a abordagem analítica de cada autor acerca das relações estabelecidas sobre e a partir da pandemia - imagens, discursos e conceitos que ilustram de forma qualitativa as relações estabelecidas a partir do fenômeno.

\subsection{COMPARAÇÃO E DIÁLOGO}

As sínteses de cada texto de cada autor foram, então, colocadas em diálogo com outros textos, para que se pudesse verificar aproximação entre conceitos e perspectivas de autores diferentes. O objetivo do artigo é desenvolver uma revisão integrativa dos conceitos e argumentos usados por autores brasileiros acerca do cenário pandêmico.

\section{DISCUSSÃO}

\subsection{SOMOS PIORES QUE O VÍRUS}

A relação predatória do humano com a natureza é o ponto de partida da reflexão do pensador indígena Aílton Krenak sobre as causas e efeitos da pandemia de covid-19. Para o ambientalista, a dor despertada pelo momento de luto, pelo confinamento dos indivíduos e interrupção da rotina pode fazer surgir em nós a desconfiança de que não estamos totalmente convictos sobre nossas decisões e escolhas na direção de uma vida considerada sustentável. "Temos de abandonar o antropocentrismo; há muita vida além da gente, não fazemos falta na biodiversidade" (KRENAK, 2020).

Em seu livro "O amanhã não está à venda" (2020) - dedicado à leitura da doença que paralisou o mundo -, Krenak afirma que somos muito piores que o vírus da covid19 em sua existência devastadora. Questiona os interesses da sociedade, em nível global, no processo de destruição do planeta e na imposição das desigualdades entre os povos, e pede atenção à oportunidade desse período de recolhimento para a formulação de respostas à inquietante pergunta: "Somos de fato uma humanidade"? (KRENAK, 2020). Integrante da aldeia Krenak, no médio rio Doce, o pensador indígena entende que deixamos de refletir sobre o sentido do que é ser humano e 
naturalizamos a existência de uma sub-humanidade, formada por caiçaras, índios, quilombolas e aborígenes, que vive numa grande miséria, sem chances de sair dela. Mas, agora, afirma ele, estamos todos sob a ameaça da extinção do sentido da vida.

Ativista do movimento socioambiental e de defesa dos direitos indígenas, Krenak entende a pandemia como a confirmação de que o modo de funcionamento do humano entrou em crise junto com seu mundo totalmente artificial. A questão, segundo ele, está na ideia de que humanidade e Terra são partes separadas, quando devem ser entendidos como natureza, pois não é possível perceber algo que não seja natureza:

Nós, a humanidade, vamos viver em ambientes artificiais produzidos pelas grandes corporações, que são os donos da grana. Agora esse organismo, o vírus, parece ter se cansado da gente, parece querer se divorciar da gente como a humanidade quis se divorciar da natureza. Ele está querendo nos desligar, tirando o nosso oxigênio (KRENAK, 2020).

A natureza é objeto da análise sobre o contexto da pandemia também pelo olhar de Tales Ab'Saber, psicanalista e professor do curso de Filosofia da Psicanálise da Universidade Federal de São Paulo (Unifesp). Em artigo assinado na edição de maio na Cult - Revista Brasileira de Cultura, sob o título "A aceleração da história e o vírus veloz", Ab'Saber afirma que o vírus da covid-19, esse agente rápido e eficaz, vem do nosso próprio mundo em desequilíbrio, construído por uma vida técnica tida por infinita. Em velocidade industrial, escreve o psicanalista, somos responsáveis pela liquidação de espécies e da diversidade biológica em todo o planeta. "Nossos próprios campos de extermínio da Terra, que evidentemente não se deixa exterminar, mas se altera de forma agonística para nós, nunca pararam de se multiplicar" (AB'SABER, 2020). Junto com o extermínio de vidas, liquidamos ainda linguagem, ontologias e cosmologias, "que poderiam muito bem nos ajudar a dar outras perspectivas para nossa jornada acelerada rumo ao nada". Nessa guerra de fundo invisível ao conceito, de um homem contra tudo o que se move ou vive, que em algum momento neste jogo do desequilíbrio, seria evidente que nós mesmos entrássemos em regime de liquidação biológica ambiental: 
Isso se dá pelo fato cotidiano de ser assim que tratamos grande parte da vida sobre a Terra: objetificação, dessolidarização, violência e extermínio. Terra e vida como commodities, resistência neutra ao progresso, ao poder e ao mercado; e não vida, diferença, espanto, convivência, maravilha, contemplação e aprendizado. Toda poesia diante da vida e do espanto diante de nós mesmos leva o selo simples do valor, e a marca pobre da mercadoria (AB'SABER, 2020).

Em "O amanhã não está à venda", Krenak afirma que sente esse momento de parada das atividades do cotidiano e de suspensão como um anzol que puxa a consciência. "É o tranco para olharmos para o que realmente importa" (KRENAK, 2020). E referese à importância de viver o tempo presente, porque, segundo ele, não sairemos dessa experiência do mesmo jeito que entramos. "Há muito tempo não programo atividades para depois. Temos de parar de sermos convencidos. Não sabemos se estaremos vivos amanhã. Temos de parar de vendermos o amanhã" (KRENAK, 2020).

\subsection{A DIMENSÃO TECNOLÓGICA DA COVID-19}

O vírus carrega a agilidade da tecnologia. Ab'Saber cita o filme "Contágio", de 2011, com direção de Steven Sorderbergh, para relacionar a potência de infecção de um vírus e seu efeito econômico global à própria potência técnica universal da época:

As comunicações e interligações de todo o planeta, com seu gasto monumental de energia, ordenadas até hoje apenas pelo movimento ascendente do capital global, fazem parte plenamente da covid-19. Aquilo que Theodor Adorno chamou, com Karl Marx, de nível de técnica da época (AB'SABER, 2020).

Vivemos a aceleração do relógio da vida e a circulação acelerada de pessoas, bens e serviços, que, na opinião do psicanalista, conduziram a humanidade a um campo de destruição articulado com a tecnologia de ponta de nosso sistema geral de tráficos e fluxos. A velocidade do mundo da catástrofe iminente do mercado global é tão grande, afirma ele, que, dado o estado técnico do tempo, quando o vírus apareceu em Wuhan, na China, ele já estava na Lombardia italiana, em Madri, em Nova York, em Teerã, em Paris e em São Paulo, bem como, evidentemente, ele já estava na Coreia e na Alemanha. Ele parasita nossas células e nossos meios de transporte: 
Avatar da velocidade da luz de nossas próprias comunicações globais, o vírus vem realmente do tempo humano degradante do espaço e tecnológico maníaco, da terra em transe globalizada total, desde as entranhas de nossa vida de desequilíbrios e recusas radicais. Em sua potência, ele foi gestado em nossas ações e nos movimentos práticos nos aviões e na internet, ações e movimentos que também nos impedem de olhar para as perdas aceleradas sempre correlatas à produtividade, para poder nos alcançar logo, em qualquer bairro, supermercado, loja ou rua do planeta. Ou ainda, simbolicamente, em todos os meios de comunicação e de sentido do mundo (AB'SABER, 2020).

Ricardo Abramovay, professor sênior do Instituto de Energia da USP, une em suas pesquisas diversas áreas como economia, sociologia e filosofia - muitas vezes dando ênfase a questões ambientais. Em 25 de março de 2020, durante a pandemia da covid-19, inaugurou um blog no UOL TAB - editoria do portal que se debruça sobre tendências e inovação.

Assim como Ab'Saber, Abramovay reconhece que desafios ainda maiores para a humanidade virão depois da covid-19 e que a atual geração tem a responsabilidade sobre o futuro da próxima. Para ele, o próprio intelecto humano pode desencadear as grandes ameaças do futuro - seja intencionalmente ou não. Em diálogo com Ab'Saber, Abramovay diz que o problema "não está no excesso de tecnologia, e sim na carência de sabedoria" (ABRAMOVAY, 2020a).

A partir de tal fundamento, o autor dialoga com Toby Ord, pesquisador de Oxford e autor de "O precipício: Risco Existencial e o Futuro da Humanidade", para percorrer os riscos existenciais que ameaçam o futuro dos seres humanos e como a inteligência e criatividade humana devem ser empregadas para antever e evitar tais catástrofes potenciais.

Uma pandemia global, a maior dos últimos cem anos, inspira o temor individual e a solidariedade coletiva com os que nos são próximos. Mas é fundamental que ela estimule também a reflexão sobre o futuro da própria espécie humana, a solidariedade entre as gerações. A única maneira de pagarmos a dívida com o que nos foi legado pelos que nos precederam é cuidando para que as gerações futuras possam florescer e desfrutar de uma vida que vale a pena ser vivida. (ABRAMOVAY, 2020a)

Citando o historiador israelense Yuval Noah Harari, Abramovay aponta dois elementos decisivos para lidar tanto com a pandemia de covid-19 quanto com possíveis crises futuras: multilateralismo democrático e cooperação internacional. Diz ele: 
Não há como responder nacionalmente a ameaças que, como o novo coronavírus, são globais. Mas o multilateralismo democrático supõe dirigentes políticos e uma elite econômica que respeitem a atividade científica, cultivem o diálogo sério e sejam capazes de despertar esperança na possibilidade de que o bom senso, o equilíbrio e a solidariedade orientem o poder cada vez maior da inteligência humana. (ABRAMOVAY, 2020a)

Portanto, Abramovay argumenta em prol de soluções compartilhadas para a crise atual e crises futuras, dentro do escopo da diplomacia e do escopo de organizações internacionais multilaterais como a ONU, OMS e OMC, que nos últimos anos têm sido desfavorecidas por discursos de cunho nacionalista.

\subsection{A POLÍTICA DO FAZER MORRER}

Em dois ensaios na llustríssima, do jornal Folha de S. Paulo, o neurocientista Sidarta Ribeiro adota a postura de um pensador interdisciplinar das ciências - tanto na forma de seu discurso quanto nas ideias que articula. Citando contemporâneos brasileiros como Laerte Coutinho, Davi Kopenawa, Ailton Krenak, Djamila Ribeiro, Atila lamarino e instituições como a Sociedade Brasileira para o Progresso da Ciência (SBPC), dialoga com diferentes campos do saber para retratar a pandemia a partir da perspectiva brasileira. Um dos textos foi publicado em 29 de março e outro em 15 de maio. No intervalo entre as publicações, o número de mortes pela covid-19 saltou de 139 para 14.962. Se em março a imagem é do "céu caindo sobre nossas cabeças" (emprestada do líder xamã ianomâmi Davi Kopenawa), em maio a metáfora é a de um carro capotando.

Com o país "capotando", Ribeiro vê tudo em câmera lenta para levantar reflexões do que nos trouxe até essa derrapada na curva. Aponta a elite brasileira como grande responsável pelo caos no país. Bolsonaro e seu entorno são a frente desse bálsamo de negação da ciência, necropolítica, subserviência aos EUA e domínio de falsos líderes religiosos. Há, no entanto, uma crítica à sociedade. Nesse cenário, a situação brasileira é parte de um problema maior: o do capitalismo predatório, "um bólido titânico rumando celeremente para o precipício da crise socioambiental" e que foi brevemente freado pela covid-19 (RIBEIRO, 2020a). 
A reflexão sobre a política do fazer morrer, a necropolítica, do pensador africano Achille Mbembe, também é citada pelo ambientalista Aílton Krenak para dar sentido à negação do presidente Jair Bolsonaro à grave crise da pandemia no país. "O presidente da República disse outro dia que brasileiros mergulham no esgoto e não acontece nada. O que vemos nesse homem é o exercício da necropolítica, uma decisão de morte. É uma mentalidade doente que está dominando o mundo" (KRENAK, 2020). O pensador indígena cita o filósofo francês Michel Foucault para abordar a lógica do capitalismo articulada à tecnologia do deixar morrer: quando o indivíduo para de produzir, ele vira uma despesa. "Não é ato falho de quem fala, a pessoa não é doida, é lúcida e sabe o que está falando" (KRENAK, 2020).

\subsection{EXPLICAÇÕES SIMPLES}

Abramovay aborda teorias conspiratórias, tema que também se relaciona com as reações à pandemia de covid-19. Em diálogo com Joseph Uscinski, professor de ciência política da Universidade de Miami e autor de "Conspiracy Theories. A primer" (Teorias conspiratórias. Uma introdução, em tradução livre), Abramovay mostra como as teorias da conspiração quebram qualquer possibilidade de diálogo extremamente necessário para o multilateralismo diplomático mencionado anteriormente.

Ele [Uscinski] mostra que teorias conspiratórias podem ser profundamente comprometedoras para a democracia, a ponto de estimular a violência. Se há muita gente convencida de que seus oponentes estão tramando por trás da cortina e se apoiam em forças poderosas e não reveladas para defender interesses inconfessáveis, é muito difícil estabelecer diálogo e muito menos negociações racionais e equilibradas. Se não tenho dúvida de que jornais, revistas e emissoras de rádio e TV (à exceção daqueles que eu leio e assisto, bem entendido) estão tramando contra os que compartilham minhas convicções, é esperado não só que eu não consuma suas informações, mas que os rejeite de forma explícita e até mesmo violenta (ABRAMOVAY, 2020b).

O ponto-chave, explica Abramovay, é que as teorias conspiratórias ganham força em situações de crise, "quando os indivíduos são colocados diante de vivências inesperadas e para as quais não existe explicação fácil” (ABRAMOVAY, 2020b). A pandemia de covid-19, com todas as questões complexas de saúde, evidencia a tese. Ele argumenta: 
São eventos que desestabilizam a vida das sociedades e abalam a capacidade interpretativa com a qual elaboramos nossas expectativas com relação aos comportamentos dos outros e ao funcionamento daquilo que compõe nosso cotidiano. Teorias conspiratórias permitem que os indivíduos recuperem a possibilidade de imprimir sentido àquilo que não conseguem mais compreender (ABRAMOVAY, 2020b).

Essa concepção, como indica Abramovay, não é nova e remete a texto de 1960 de Theodor W. Adorno, traduzido e publicado no blog "A Terra É Redonda"[4], no qual sugere que há dois expedientes conspiracionistas usados por dirigentes políticos: se colocar permanentemente como mártir; e como alguém que conhece os bastidores do que não deveria ser revelado. Ressoando Ribeiro e Krenak, Abramovay aponta como saída desse cenário todo a empatia e a compaixão:

Em um quadro tão preocupante, a esperança é que a queda na popularidade de Jair Bolsonaro (e também de Donald Trump) possa abalar a coerência interna das visões conspiratórias que os sustentam e abrir caminho a que argumentos, fatos e, sobretudo, empatia e compaixão tomem o lugar daquilo com que hoje tantas forças prosperam, mundo afora: o culto ao ódio (ABRAMOVAY, 2020a).

Apesar das evidentes preocupações, Abramovay demonstra otimismo em seus artigos. Em abril (ABRAMOVAY, 2020c), ao abordar as manifestações contra o isolamento social no Brasil e nos EUA, o autor argumenta que as reações são semelhantes em ambos os países. Embora as manifestações nos EUA e no Brasil sejam reforçadas pelos presidentes e causem muito barulho, elas não parecem refletir as opiniões públicas, uma vez que pesquisa do Datafolha[5] em abril indicava que $76 \%$ dos brasileiros eram favoráveis ao isolamento, enquanto a universidade de Yale apontava que $84 \%$ dos estadunidenses também eram favoráveis[6].

O contraste entre $\mathrm{o}$ barulho produzido pelas manifestações e o estado da opinião pública torna-se ainda mais flagrante quando se sabe que, pela pesquisa de Yale, os norte-americanos confiam menos nas informações sobre o novo coronavírus transmitidas por Trump do que naquelas que vêm de seu adversário na corrida presidencial em 2020, o democrata Joe Biden (ABRAMOVAY, 2020c).

Para Abramovay, tal contraste é também sinônimo de otimismo: a maioria está consciente da união e da responsabilidade necessária para enfrentar momentos 
assim. Se temos a impressão de barulho, é porque eles são amplificados por líderes irresponsáveis, mas não porque são maioria.

Combustível para as teorias conspiratórias durante a pandemia no Brasil, o isolamento social, combatido desde o início da crise sanitária pelo presidente da República, foi tema de algumas edições da coluna semanal do biólogo e professor da Universidade de São Paulo, Fernando Reinach, no jornal O Estado de S. Paulo, que se dedica a refletir sobre os desdobramentos da covid-19 no país.

No artigo intitulado "Um plano arriscado", publicado em 30 de maio, refere-se ao impasse da medida no estado paulista: a quarentena foi longa demais, mas não se mostrou rígida suficiente para reduzir o espalhamento do vírus - teve início em 23 de março e prolongou-se até 31 de maio. Cumprido o prazo de restrições, o governo paulista afirmou não ter condições para impor o lockdown e iniciou, em $1^{\circ}$ de junho, o relaxamento gradual das medidas de restrição de mobilidade. Reinach lamentou a decisão do poder público e, principalmente, o apoio de profissionais da saúde à medida. Segundo ele, os critérios para abertura do comércio e funcionamento de shoppings e parques não devem ser baseados nas estatísticas da doença porque não indicam exatamente os números do que está acontecendo no tempo presente. Os dados apresentados referem-se a fatos de semanas atrás.

\begin{abstract}
Nenhum país utiliza somente dados de casos hospitalizados, mortes registradas e modelos epidemiológicos para guiar a abertura da economia. Todos implementaram um programa robusto de testes capaz de informar o governo sobre como o vírus está se espalhando em tempo real. Aí esses dados, juntamente com os dados de novas mortes, novos casos e ocupação hospitalar são usados para detectar novos focos e estancá-los. É assim que está sendo feito em todo o mundo. Nosso plano de abertura é arriscado e seus resultados são imprevisíveis exatamente porque ele não dispõe desse tipo de informação (REINACH, 2020a).
\end{abstract}

$\mathrm{Na}$ mesma época em que Reinach escreve os textos analisados neste artigo, o presidente da República tecia um discurso de oposição entre as medidas restritivas para contenção da doença e a continuidade de um suposto desenvolvimento econômico - de acordo com a autoridade política, economia e saúde estariam em 
oposição e seriam irreconciliáveis. É notável que Reinach, em seus textos, tente fugir deste discurso de oposição.

\title{
3.5 NÓS E ELES
}

Autora de uma série de obras sobre o racismo no Brasil, a historiadora Lilia Schwarcz abordou, em fevereiro, a covid-19 pelas lentes da xenofobia em sua coluna no jornal digital Nexo.

No momento, o Brasil ainda não tinha casos confirmados da doença e ela não havia sido declarada com pandemia pela Organização Mundial da Saúde. Schwarcz, no entanto, mostrava que o país já manifestava sintomas de outro problema relacionado à doença: o racismo.

\begin{abstract}
Nas redes sociais, em locais públicos e, em especial, em lugares fechados como ônibus, metrôs, shoppings, teatros, supermercados e cinemas, pessoas de ascendência asiática têm recebido agressões verbais e ofensas, além de piadas relacionadas a uma suposta falta de higiene por parte dessas populações. É fundamental não transformar a epidemia em um problema racial, ou imaginar que a China seria um "celeiro de doenças". Não é - e não vale se escudar nesse tipo de argumento para tratar mal aqueles que têm tanto a ver com essa história quanto nós mesmos. (SCHWARCZ, 2020a)
\end{abstract}

Embora a covid-19 seja uma doença nova, o hábito de segregar pessoas por conta de surtos é antigo, como argumenta a historiadora. E cita uma série de doenças, como a hanseníase, que foi associada a pecadores; a peste bubônica, tratada pela Igreja Católica como castigo divino a judeus; a cólera, associada aos indianos, e a tuberculose, relacionada às classes mais vulneráveis, entre outras.

Em comum há sempre o fato de as doenças, embora causadas por agentes nãohumanos, ser atribuída como responsabilidade do "outro" como forma de justificar a separação social e o racismo - que a autora define como "qualquer manifestação, individual ou coletiva, que justifique as diferenças, hierarquias e desigualdades entre seres humanos a partir de uma suposta realidade biológica, em geral tomada de maneira depreciativa" (SCHWARCZ, 2020a).

Sobre o racismo, a autora, então, pontua: 
Ora, uma coisa é lidar com a doença e buscar debelá-la, ainda mais quando ela assume taxas epidêmicas. Outra é vincular uma moléstia a um grupo social, uma raça, e assim passar a discriminá-lo. Raça é um conceito que não se justifica biologicamente e que passou a ser usada apenas com fins políticos. Não existe raça, pois, apenas raça social; é uma invenção social. Também não vale culpar animais que em geral são portadores infectados. (SCHWARCZ, 2020a).

Sessenta dias após a publicação de tal texto, em 28 de abril, o Brasil, pelos números oficiais, chegaria em 5.017 óbitos causados pela covid-19, ultrapassando a China. Ainda assim, o preconceito com chineses e a associação deles com o vírus continuou sendo manifestada no país, inclusive por agentes do governo federal.

A socióloga Angela Alonso, pesquisadora sênior do Centro Brasileiro de Análise e Planejamento, também discute, no jornal Folha de São Paulo, questões de segregação durante a pandemia no Brasil. Segundo dados divulgados pelo Ministério da Saúde em 10 de abril, embora pretos e partos representassem $23,1 \%$ dos brasileiros hospitalizados com Síndrome Respiratória Aguda Grave, eles chegavam a $32,8 \%$ entre os mortos por covid-19[7]. Alonso chama a atenção para a segregação:

Faltam estatísticas completas sobre o perfil dos falecidos, mas é só ligar a TV para saber quem compõe a maioria. São os pobres, são os negros. Nenhuma bravata presidencial pode desmenti-lo. Ao deixar ao deus-dará o controle da pandemia, o governo federal condena um perfil bem específico de brasileiros ao cadafalso. (2020a).

Para a autora, o governo Bolsonaro opta por uma política de "imunização darwinista" contra negros e pobres. Alonso destaca que a negligência com a saúde de tal população é continuação de políticas do passado brasileiro:

Em 1888, libertaram-se cerca de 700 mil escravos oficiais —afora os ilegais, pois as leis do Ventre Livre e dos Sexagenários nunca se efetivaram completamente. A norma demorou a vigorar e nada proveu para os libertos. Muitos de seus descendentes estão no mesmo desamparo a que a Monarquia os relegou e no qual a República os mantém. No ano passado, 1.054 pessoas, informa também o UOL, foram encontradas em cativeiro no Brasil. Basta olhar a cor delas e a dos moribundos nas filas hospitalares para ver que este é um país assombrado pelos fantasmas de seu passado. $E$ presidido por um deles. (ALONSO, 2020a) 
Os preconceitos que a pandemia evidencia não são só com chineses, índios, negros e pobres. São também com os idosos, como destaca Schwarcz em outro texto no jornal Nexo.

A covid-19 é uma doença especialmente perigosa para pessoas idosas. Entre a população de 80 anos ou mais, por exemplo, os índices de letalidade chegam a 14,8\%, segundo dados compilados na China[8]. Para Schwarcz, no entanto, isso não é justificativa para tratar idosos como decrépitos. "Infelizmente, porém, é exatamente isso que nosso presidente tem feito com seus discursos errantes; vem travando uma guerra e polarizando os brasileiros entre aqueles 'com saúde' e os 'sem saúde' (SCHWARCZ, 2020b), aponta a autora que cita diversas declarações preconceituosas do presidente com os mais velhos.

Disse ele no dia 27 de março, revelando sua conhecida falta de solidariedade: "Infelizmente algumas mortes terão, paciência, acontece e vamos tocar o barco. Vão morrer alguns pelo vírus?" Tentando mostrar alguma empatia, ainda propôs, nesse mesmo dia, "contratar hotéis para abrigar idosos ainda não contaminados" durante a pandemia do coronavírus. (SCHWARCZ, 2020b)

Schwarcz mostra que os preconceitos contra idosos não são algo inédito. Ao longo da História, houve ciclos em que eles foram considerados sábios a serem respeitados e em outros que foram vistos como figuras melancólicas. Diz ela:

\begin{abstract}
Não há como traçar uma linha evolutiva na história: existiram avanços e retrocessos nas concepções sobre velhice. No entanto, a literatura especializada destaca a importância do final do século 19 e início do 20, quando são criadas as áreas médicas da gerontologia e da geriatria, que se transformam em disciplinas voltadas para a saúde dos idosos, mas também para a sua boa inserção social. O que percebemos atualmente é como vai-se empurrando a fronteira do envelhecimento para cada vez mais longe, em termos cronológicos, ao mesmo tempo que persistem uma série de preconceitos associados a essa faixa etária. (SCHWARCZ, 2020b)
\end{abstract}

Com o avanço da medicina e de áreas especializadas no cuidado do idoso, como a gerontologia, a população idosa cresceu quantitativamente, mas continuou sendo vítima de uma visão que descreve a velhice como uma "etapa inevitável da decadência, declínio e que apenas antecederia à morte: uma longa espera a lugar nenhum" (SCHWARCZ, 2020b). Durante a pandemia, incentivados pelas declarações 
de Bolsonaro, muitos seguidores do presidente passaram a compartilhar piadas e imagens tratando os idosos como responsáveis pela pandemia.

Para especialistas em envelhecimento, a prática pode surtir efeito grave. Isto é, se a ideia é a proteção da coletividade no combate ao coronavírus, o maior receio é que a disseminação desse tipo de conteúdo piore e renove o preconceito já existente contra o idoso e coloque nele a culpa da pandemia. Além do mais, o "isolamento vertical", defendido pelo presidente, não atenta para o perfil de sua população, que vive em casas pequenas que abrigam famílias grandes, e tampouco para o fato de que, em muitos casos, é a aposentadoria do cidadão sênior que garante o sustento de uma família inteira. (SCHWARCZ, 2020b)

A argumentação de Schwarcz caracteriza de forma não explícita o discurso do presidente da República como um discurso necropolítico, no qual determinadas vidas só têm valor para a sociedade enquanto úteis em relação a determinado propósito. Assim, dentro desta lógica perversa, a partir do momento em que a os idosos "atrapalham" a economia, tornam-se passíveis de morte.

\subsection{DEPOIS DA PANDEMIA}

Citando iniciativas como o "Fórum do Amanhã" e o "Movimento 2022: o Brasil que Queremos", Sidarta Ribeiro aponta que "a saída desse atoleiro exige o resgate da alma brasileira no que ela tem de mais amoroso, solidário e criativo" (RIBEIRO, 2020a). Ou, como havia dito em março:

Que venha então a cura. Finalmente teremos a chance de olhar para dentro e, com toda a sabedoria acumulada desde a aurora paleolítica, criar uma sociedade digna de tod@s human@s e demais animais, plantas, fungos, algas, bactérias... e vírus (RIBEIRO, 2020b).

Já Krenak cita Albert Camus para expressar o receio de que a dor da pandemia não conduza a humanidade à reflexão tão necessária para salvar a natureza: a peste pode ir e vir embora sem que o coração do homem seja modificado. "Tomara que não voltemos à normalidade, pois, se voltarmos, é porque não valeu nada a morte de milhares de pessoas no mundo inteiro" (KRENAK, 2020). Para o líder indígena, depois da angústia da pandemia e da vivência da abertura de um novo campo de possibilidades de sentido à vida, não será possível, de repente, ligar todas as máquinas e carros ao mesmo tempo. "Seria como se converter ao negacionismo, 
aceitar que a Terra é plana e que devemos seguir nos devorando. Aí, sim, teremos provado que a humanidade é uma mentira" (KRENAK, 2020).

Ab'Saber relaciona os efeitos da pandemia com o desdobramento de um tipo de renovação necessária. Ele refere-se, portanto, ao que o vírus pode significar ou performar, fazer ou criar na vida dos homens:

O movimento coletivo e político que tomou conta do planeta em 2020 se dá diante da máxima alteridade da consciência das ilusões humanas, tão vitais na constituição da cultura, da proteção ante a presença concreta da morte em toda a trama da nossa vida (AB'SABER, 2020).

O psicanalista afirma que a mensagem do vírus, ainda que planetária e múltipla, é, na verdade, muito simples: precisamos desacelerar. Em seu artigo na revista Cult, chama a atenção do leitor para a necessidade de reduzir a velocidade do que ele chama de velocidade do sonho subjetivante da vida da forma mercadoria, sua excitação fetichista e atuação sobre a vida. É preciso de fato controlar o vírus:

Nosso modo de viver se tornou definitivamente viral, mortífero. Precisamos de menos velocidade, de menos ritmo, de menos excitação generalizada orientada para a reprodução do poder mundial de concentração e investimentos, de modo que tenhamos um mundo de algumas qualidades vitais humanas de algum modo livres de preço. A renda básica universal, compromisso de todos com todos, também aparece exatamente aí. A formação sociológica principal que sustenta tal inferno do poder na Terra é nossa subjetivação para o consumo. Nosso fascismo de consumo, que engoliu a subjetivação política no mundo do século 20 (AB'SABER, 2020).

As mudanças provocadas pelo vírus podem influenciar nossas práticas sociais, hábitos de consumo e relação com a natureza, como desejam os autores selecionados para esse artigo. Podemos demonstrar atitudes mais humanas, como reivindica Krenak, ou exercitar a solidariedade, como calcula Abramovay. Mas o coronavírus modificará também nosso corpo biológico, além da subjetividade, claro. $\mathrm{Na}$ coluna semanal Ciência, no jornal O Estado de S. Paulo, em 3 de maio, o biólogo Fernando Reinach afirma que o coronavírus pode exercer pressão na "evolução" da espécie humana. O vírus da covid-19 pode alterar a evolução do Homo Sapiens porque ele não atua de maneira indiscriminada. Há pessoas que, no contágio com o 
vírus, quase não apresentam sintomas. E outras podem morrer. Até agora, pesquisas indicam que a doença afeta mais homens que mulheres, e mais adultos que crianças.

Todas essas características do novo coronavírus garantem que ele deve alterar sutilmente a frequência dos indivíduos mais atacados e dos indivíduos resistentes. Esse processo de seleção natural vai seguramente levar a mudanças sutis nas características do Homo Sapiens que serão sentidas ao longo das próximas décadas caso uma vacina, ou uma cura, não for descoberta (REINACH, 2020c).

Reinach ainda faz um alerta a propósito da pergunta de Krenak, nas linhas iniciais desse artigo, sobre a nossa força exterminadora e se ainda somos humanidade. De acordo com ele, é preciso lembrar que as outras espécies com as quais compartilhamos o planeta, e para as quais somos letais como a doença, não podem proteger-se do Homo Sapiens (REINACH, 2020b). Elas estavam e continuam à nossa mercê, assim como hoje nós, seres humanos, estamos à mercê do coronavírus.

\section{CONCLUSÃO}

Os autores selecionados para este artigo, durante os quatro primeiros meses da quarentena (março a junho de 2020), alinham seus discursos na direção, principalmente, de três temas frequentemente presentes no debate público no país. São eles: a pandemia que escancara e aprofunda a desigualdade social, o incontrolável vírus que deflagra a intervenção predatória do humano na natureza e a ciência ultrajada pela desinformação que despedaça a já tão frágil coesão social brasileira e empurra a maioria rumo ao precipício. Intelectuais de diversas áreas do conhecimento fazem a leitura de um mundo em desequilíbrio e com alguma oportunidade de encontrar na pandemia boas razões para profundas transformações sociais, econômicas e políticas.

O pensador indígena Aílton Krenak relaciona a ameaça da extinção do sentido da vida, provocada pelo risco de morte da ação do vírus implacável, ao hábito do humano de viver um mundo artificial, totalmente apartado da natureza. E questiona se essa parada repentina na vida ordinária, causada pela necessidade do distanciamento 
social, levará esse humano à reflexão sobre a insistência no exercício desmedido do antropocentrismo.

O psicanalista Tales Ab'Saber também encaminha seus questionamentos para o modo de um viver tecnocêntrico adotado pelo humano e que impõe igualmente velocidade de contágio e de morte. A mobilidade do vírus segue nossos padrões de existência e é tão potente quanto nossa força produtiva. $O$ pensador Ricardo Abramovay soma à questão do excesso de tecnologia em nossos hábitos, apontada por Ab'Saber, a falta de sabedoria em sociedades que desprezam o meio ambiente. E aponta para a necessidade de firmarmos o compromisso com as próximas gerações na construção de uma vida que verdadeiramente faça sentido.

Neste escasso ambiente de reflexões, mas repleto de conexões e interações, Abramovay ainda escreve sobre a ciência em constante constrangimento provocado pelo confronto com a desinformação e as teorias da conspiração, impulsionadas pela força do negacionismo como narrativa altamente convincente em períodos de incerteza sobre o futuro. O caos informacional então se amplia quando o Estado orienta medidas de fechamento e abertura do comércio, na condução do afrouxamento da quarentena, baseado em números de contágios e de mortes desatualizados, segundo o biólogo Fernando Reinach. Um plano arriscado, informa o título do artigo publicado na imprensa brasileira, e, segundo ele, com resultados imprevisíveis. Mas em plena sintonia com as ordens do capitalismo e do neoliberalismo: a "vida" não pode parar.

Para o neurocientista Sidarta Ribeiro, o capitalismo predatório está entre os grandes responsáveis pelo caos em várias partes do planeta durante a pandemia de covid-19. No Brasil, a situação foi agravada pela participação do presidente Bolsonaro e de todo o seu entorno, que fazem reverberar a negação da ciência, o exercício da necropolítica e a subserviência aos Estados Unidos. Neste grupo de "culpados", Sidarta inclui ainda a elite brasileira.

A grave questão da desigualdade social e a falta de assistência às camadas mais vulneráveis da sociedade brasileira, durante a pandemia, estiveram presentes em 
praticamente todos os textos que passaram pela leitura dos autores deste artigo. $\mathrm{O}$ exercício da necropolítica - o fazer morrer do genocídio que age, sistematicamente, contra pretos e índios no país - é apropriadamente abordado na maioria dos textos que aprofundaram as discussões sobre os efeitos sociais da pandemia no país. A historiadora Lilia Schwarcz, em seu texto, refere-se à instantânea manifestação do racismo na relação dos brasileiros com as populações asiáticas; e a socióloga Angela Alonso chama a atenção para a descarada (e declarada) negligência do Estado com a saúde dos pretos e dos idosos. O baixo exercício de solidariedade pelo brasileiro não fica de fora da discussão.

Para o pós-pandemia, os intelectuais dão pistas sobre por onde podem ser iniciadas as mudanças para uma vida com mais equilíbrio e menos desigualdades, mas, ao mesmo tempo, impõem suas desencantadas apostas sobre nenhum tipo de aprendizado.

\section{BIBLIOGRAFIA}

ABRAMOVAY, Ricardo. Covid-19: riscos globais exigem gestão racional e cooperativa. UOL TAB, 25 de abril de 2020. Disponível em: https://ricardoabramovay.blogosfera.uol.com.br/2020/03/25/covid-19-nao-ha-comoresponder-nacionalmente-a-ameacas-globais/: Acesso em 15 de junho de 2020a.

. Quem está por trás disso? Pandemia turbina teorias conspiratórias. UOL TAB, 06 de maio de 2020. Disponível em: https:/tab.uol.com.br/colunas/ricardoabramovay/2020/05/06/teorias-conspiratorias-prosperam-mais-na-pandemia.htm: Acesso em 15 de junho de 2020b.

Covid-19 pode abrir caminho para o fim do radicalismo e da polarização. UOL TAB, 22 de abril de 2020. Disponível em: https://tab.uol.com.br/colunas/ricardoabramovay/2020/04/22/covid-19-pode-abrir-caminho-para-o-o-fim-do-radicalismo-epolarizacao.htm: Acesso em 22 de abril de 2020c. 
AB'SABER, Tales. A aceleração da história e o vírus veloz. Cult - Revista Brasileira de Cultura, v. 257, p.32-43, 2020.

ALONSO, Angela. Contra negros e pobres, Bolsonaro prefere imunização darwinista. Folha de S. Paulo, 16 de maio de 2020. Disponível em https://www1.folha.uol.com.br/colunas/angela-alonso/2020/05/contra-negros-epobres-bolsonaro-prefere-imunizacao-darwinista.shtml: Acesso em 18 de maio de 2020.

DOMINGUES, Ivan. O intelectual público, a ética republicana e a fratura do éthos da ciência. Sci. stud. [online]. 2011, vol.9, n.3 [cited 2020-05-14], pp.463-485. Available from: <http://www.scielo.br/scielo.php?script=sci_arttext\&pid=S1678$31662011000300002 \& \operatorname{lng}=e n \& n r m=i s 0>$. ISSN 1678

3166. http://dx.doi.org/10.1590/S1678-31662011000300002:

KRENAK, Ailton. O amanhã não está à venda. São Paulo: Companhia das Letras, 2020.

RIBEIRO, Sidarta. Brasil está capotando com Bolsonaro e coronavírus. Folha de S. Paulo, 15 de maio de 2020. Disponível em https://www1.folha.uol.com.br/ilustrissima/2020/05/brasil-esta-capotando-combolsonaro-e-coronavirus-afirma-sidarta-ribeiro.shtml: Acesso em 18 de junho de 2020a.

. Coronavírus e fascismo de Bolsonaro nos fazem esperar por nova era. Folha de S. Paulo, 29 de março de 2020. Disponível em https://www1.folha.uol.com.br/ilustrissima/2020/03/coronavirus-e-fascismo-debolsonaro-nos-fazem-esperar-por-nova-era-diz-sidarta.shtml: Acesso em 18 de junho de 2020b.

REINACH, Fernando. Um plano arriscado. O Estado de S. Paulo. 30 de maio de 2020. Disponível em https://ciencia.estadao.com.br/noticias/geral,um-planoarriscado,70003319253: Acesso em 17 de junho de 2020a. 
. Coronavírus exerce pressão evolutiva sobre o homo sapiens. O Estado de S. Paulo. Disponível em https://www.estadao.com.br/infograficos/saude,coronavirusexerce-pressao evolutiva-sobre-o-homo-sapiens,1091113: Acesso em 17 de junho de 2020b.

SCHWARCZ, Lilia. Epidemia e racismo: paredes de uma mesma equação. Nexo. Disponível em https://www.nexojornal.com.br/colunistas/2020/Epidemias-e-racismopartes-de-uma-mesma-equação: Acesso em 17 de junho de 2020a.

. Ninguém tem o direito de discriminar quem vai viver e quem há de morrer. Nexo. Disponível em https://www.nexojornal.com.br/colunistas/2020/Ninguém-tem-odireito-de-discriminar-quem-vai-viver-e-quem-há-de-morrer: Acesso em 17 de junho de 2020b.

\section{APÊNDICE - REFERÊNCIAS DE NOTA DE RODAPÉ}

4. Disponível em https://aterraeredonda.com.br/lideranca-democratica-emanipulacao-de-massas/

5. Disponível em https://www1.folha.uol.com.br/equilibrioesaude/2020/04/para-76-aspessoas-devem-ficar-em-casa-diz-datafolha.shtml

6. Disponível em https://climatecommunication.yale.edu/publications/american-publicresponses-to-covid-19-april-2020/

7. Disponível em < https://www1.folha.uol.com.br/cotidiano/2020/04/coronavirus-emais-letal-entre-negros-no-brasil-apontam-dados-da-saude.shtml>

8. Disponível em < https://www.saude.gov.br/images/pdf/2020/marco/20/20200318ProtocoloManejo-ver002.pdf>

Enviado: Novembro, 2020.

Aprovado: Novembro, 2020. 